A critique of water scarcity discourses in educational policy and textbooks in Jordan

\author{
Hussam Hussein ${ }^{12}$ \\ ${ }^{1}$ Water Security Research Centre and Tyndall Centre for Climate Change Research, School of \\ International Development, University of East Anglia (UEA), Norwich, UK - $\underline{\text { h.hussein@uea.ac.uk }}$ \\ ${ }^{2}$ Issam Fares Institute for Public Policy and International Affairs, American University of Beirut \\ (AUB), Beirut, Lebanon
}

FUNDING: My gratitude is due to the Council for British Research in the Levant (CBRL) who granted me a travel award to conduct data collection for this research.

\begin{abstract}
This article investigates the representation of water scarcity in Jordanian textbooks to understand its role on improving education on environmental sustainability. People's understanding of an issue guides their actions towards finding and implementing appropriate solutions to what they perceive as a problem. Discourses are key in constructing people's understanding of an issue, in this case of water scarcity. This article shows the role of textbooks and of the educational system in constructing a discourse of water scarcity that frames the issue as due to nature, to neighbouring countries, and to refugees. It then demonstrates how this framing opens and drives towards supply side solutions. It discusses to what extent the representations of water scarcity drive towards a better education on environmental sustainability.
\end{abstract}

KEYWORDS: Jordan; water scarcity; textbooks; discourse analysis; educational policy.

\title{
INTRODUCTION
}

Mass media emphasise that Jordan is one of the three most water scarce countries in the world (Namrouqa 2012, Namrouqa 2014). Millions of refugees from the region in particular from Syria since 2012 - are arriving in Jordan following the regional political instability (Rawashdeh 2012, MWI 2013). Population growth and low precipitation are the main reasons for water scarcity in Jordan (Haddadin 2006). These are only some of the assumptions underpinning the discourse of water scarcity in Jordan. While the issue of water scarcity in Jordan has been researched mainly by 
engineers, the discourse of water scarcity has been taken for granted and has not been investigated. Overall, a discursive approach to water scarcity in Jordan is still overlooked. Investigating the construction of the discourse would show the power dynamics and interests behind and around national policies and transboundary water governance. This article investigates the construction of the discourse of water scarcity in the case of Jordan through the lens of the Jordanian educational system, as textbooks have a central role in constructing people's perceptions.

The decision to focus on textbooks and primary education is due to the key role that they play in building shared understandings of national issues, including for instance in state building and nationalism (Williams 2014). Primary education and textbooks are also the central place and tool to advance and research education on environmental sustainability (Caravita, Valente et al. 2008, Mahasneh et al., 2017). For Podeh, textbooks on the one hand transmit "accepted historical narratives; on the other, they alter - or rewrite - the past in order to suit contemporary needs" (Podeh 2000: 66). For Mehlinger (1985: 287), textbooks are powerful as they "are responsible for conveying to youth what adults believe they should know." They are powerful "in their capacity to convey a uniform, approved, even official version of what youth should believe" (Mehlinger 1985: 287). In an interview with a director of the Jordanian Ministry of Education, the director underlined the importance of their task, as "textbooks are very important and a sensitive issue as they build and construct national culture and what people take for granted" (Interview 1). However, social scientists and researchers in Jordan fail to investigate the role of textbooks in their social and political dimension of constructing a collective perception of the water issue in the country. Discourse analysts in the region rarely analyse textbooks with a focus on the water discourse, but do rather focus on nation building (Podeh 2000), tribes (Massad 2001), and on the Palestinian-Israeli conflict (Podeh 2000: 65-66, Podeh 2005).

First, this article briefly discusses what it is meant by education for environmental sustainability. Second, it provides general background context of water resources in Jordan. Third, in order to investigate the role of textbooks and of the educational system in constructing shared understandings of the issue of water scarcity in Jordan, this article presents the methodological and theoretical approach underpinning this article and then the methods deployed for the collection and analysis of the data. Fourth, it examines the textbooks adopted in Jordan with 
reference to how they present the issue of water scarcity. Finally, a discussion section presents the main findings and contributions of this article.

\section{EDUCATION FOR ENVIRONMENTAL SUSTAINABILITY}

Stevenson et al. (2013) underline the necessity to be aware of the theoretical, historical, and epistemological orientations of environmental education that informs researchers' work in the field (Stevenson, Brody et al. 2013). Gough (2013) notes that environmental education can be traced back to Carson's (1962) Silent Spring and similar works of the 1960s (Gough 2013). Marcinkowski et al. (2013) also point out the educational movements that created the conditions for environmental education in the 1960s, from the Nature Study Movement at the beginning of the last century; to Outdoor Education Movement in the 1920s, and from Conservation Education Movement in the 1930s, to Ecology Education in the 1950s and the Education for Sustainable Development Movement of the 1990s (Marcinkowski, Ucheit et al. 2013). Gough (2013) emphasizes the importance of the 1990s for situating environmental education within environmental sustainability (Gough 2013). Sitarz (1993) highlighted that Agenda 21, produced at the UN "Earth Summit" in Rio de Janeiro in 1992 , mentioned that the greatest challenge to education in the $21^{\text {st }}$ century will be to help citizens to understand and prepare for a future of sustainable development (Sitarz 1993). Education for environmental sustainability is key and central to achieve this goal. Education for environmental sustainability means educating the wider population, and in particular the youth, for issues related to the environment and its sustainability. As noted by Newport, Chesnes, and Lindner (2003), “environmental sustainability" comes from the term sustainability, but focusing on the environment rather than on the social and economic forces (Newport, Chesnes et al. 2003: 358359). While sustainable development is currently still a contested term, Jacobs (1993) identified three key elements of most definitions: 1) considerations of the environment in relation with the economy; 2) commitment to social equity in relation to the environmental costs and benefits both geographically and across generations; 3 ) development to be understood not only in economic terms, but also in terms of quality of life (Jacobs 1993). Wright (2002) has explored the different frameworks and definitions for environmental sustainability in higher education and how different universities and academic institutions have implemented them (Wright 2002). Wright (2002) notes that there is a gap in the literature on investigating how the international 
declarations on education for environmental sustainability are being implemented at the national level. Tilbury (1995) explains the difference between education for environmental sustainability of the 1980s and of the 1990s. In the 1980s, environmental education was presented in the classrooms without supporting critical thinking around environmental issues, supporting instead an apolitical, naturalist, and deterministic approach to the environmental issues (Tilbury 1995). Reports that called for acknowledging the role of schools and students in achieving environmental sustainability have failed to be incorporated into the textbooks and into the education of the 1970s and 1980s (Tilbury 1994). Instead, in the 1990s education for environmental sustainability addressed educating for sustainability not as a goal, but in the long term, and aiming at making a difference (Tilbury 1995). The focus has changed from environmental education to education for environmental sustainability, including the sustainability aspect, which incorporates the long-term approach, and the call for an active change. In this way, there is a necessity for empowering students and citizens to contribute to environmental sustainability.

\section{GENERAL BACKGROUND CONTEXT}

This section presents contextual background information useful for the analysis of the issue of water scarcity in textbooks in the next section. Concerning the population of Jordan, it increased from 225,000 during the Emirate of Jordan in 1922 (Haddadin 2006: 7) to more than 9.5 million in 2015 (Ghazal 2016), mainly due to the several waves of refugees of Palestinian, Lebanese, Iraqi, and Syrian origins, who fled their home countries due to wars and occupations.

The issue of water scarcity in Jordan is informed by what hydrologists define as a situation of water shortage due to the climatic and natural characteristics of the territory: rainfall, which usually occurs in between October and April, ranges between $50 \mathrm{~mm}$ in the Badia and $650 \mathrm{~mm}$ in the Highlands, with over $90 \%$ of the country receiving less than $200 \mathrm{~mm}$ per year and an overall average of $80 \mathrm{~mm}^{1}$ (FAO 2009: 233). In addition, studies have shown a trend of decreased rainfall over the past 75 years, suggested at about $25 \%$, which has also negatively impacted surface water resources and recharge of groundwater basins in Jordan (Jassim and AlRaggad 2009:

\footnotetext{
${ }^{1}$ As of 2005, according to FAO. 2014. AQUASTAT database, Food and Agriculture Organization of the United Nations (FAO). Website accessed on [30/12/2014 13:40]
} 
356). The generally accepted figure of $90-95 \%$ evapotranspiration losses means that only 5\% of rainfall recharges the groundwater resources (ISSP 2012: 63).

Concerning the water resources in Jordan, surface water resources constitute two-thirds of the water resources in Jordan. Three rivers may be found in Jordan, the Jordan, the Yarmouk, and the Zarqa, the first two being transboundary. The Yarmouk and the Zarqa are two of the main tributaries of the Lower Jordan River (LJR) (FAO 2009: 236-237). However, the Yarmouk and the Jordan Rivers, which represent the biggest surface water available in Jordan, originate partly in Jordan and partly in other countries, and the country of Jordan is therefore constrained by treaties on their use (Garber and Salameh 1992: 12; Hussein and Grandi 2015; 2017).

Given the limited access that Jordan has to its surface water resources due to their transboundary nature, it mainly relies on its groundwater resources, most of which are completely within Jordanian boundaries. All the groundwater basins are indeed over-exploited, with an average over-abstraction that stands at $159 \%$ of the renewable average of recharge, ranging between $146 \%$ for the minor aquifers to $235 \%$ for the major ones. This is resulting in a decrease not only of their quantity due to lower recharge, but also of their quality (El-Naqa and Al-Shayeb 2009: 2380).

In 2010 groundwater represented the main source of water supply, with a total of approximately $54 \%$ of the total water supply - over $500 \mathrm{MCM}$; surface water supply represented only $33 \%$, meaning $286 \mathrm{MCM}$; while treated wastewater accounts for more than $13 \%$ of the total water supply, meaning 117 MCM (MWI, Water Budget Projected Demand and Resources 2010-25, 2012, in Yorke, 2013: 14). While surface water represents a higher proportion of water resources, at around two thirds of the total water resources in Jordan, in practice two of the three major rivers in Jordan are transboundary, and therefore Jordan is bound in their usage by bilateral agreements. Therefore, groundwater resources are the most important sources of water supply, and these are currently over-exploited. Concerning water use per sector, agriculture accounts for $58 \%$ of the share in 2011 , municipal use for $37 \%$, industry use for 5\%, and 1\% for other sectors (MWI 2014).

\section{METHODOLOGICAL AND THEORETICAL APPROACH}

The guiding research question of this study is:

- How does the Jordanian educational system construct the discourse of water scarcity? 
Sub-research questions are:

- What causes of water scarcity are reproduced in the Jordanian textbooks?

- What solutions to water scarcity are suggested to students in the textbooks?

This article starts from the epistemological constructivist assumption that while an objective reality exists, it cannot be perceived objectively, and therefore our knowledge of reality is mediated. For constructivists, knowledge is not objective (Murphy 1997: 5), but as Von Glasersfeld puts it, "it is made up of the network of things and relationships that we rely on in our living, and on which, we believe, others rely on, too" (Von Glasersfeld 1995: 7). For Kincheloe, "there is no truly objective way of seeing things" (Kincheloe 2005: 8). As noted by Gough and Price (2004: 4), "we do not interpret these philosophers to be questioning belief in the real but confidence in its representation. As Richard Rorty (1979) puts it, "to deny the power to 'describe' reality is not to deny reality' (p.375) and 'the world is out there, but descriptions of the world are not' (Rorty, 1989: 5). Representations of the world are products, artefacts or effects of particular sets of historical and linguistic practices" (Gough and Price 2004: 4). In a nutshell, while there is an objective reality out there, descriptions and representations of it are mediated by our own lenses.

People's understanding of an issue, in this case of water scarcity, shapes the solutions they would identify to solve what they perceive as a problem. Discourses have a central role in mediating people's understanding of the issue. Hence, constructing and deploying discourses is very important to be able to shape and drive towards certain solutions. Nevertheless, the literature on water resources management in Jordan has so far taken for granted the discourse, focusing on the solutions to solve the issue of water scarcity, rather than understanding who constructs the discourse, how, and what are their interests. The latter approach allows unfolding actors' interests behind constructing the discourse in a specific way, and driving towards certain solutions; this approach benefits the non-powerful actors, in particular the marginalised communities, those that are unjustly blamed for causing water scarcity in the country, and the environment. As shown by Hussein (2016), all actors in Jordan agree that water scarcity is an important issue in Jordan, but they disagree on the emphasis on the different causes of water scarcity. Consequently, they disagree on how to solve the issue of water scarcity (ibid.). The role of the Jordanian textbooks and of the educational system in building this shared understanding regarding the issue of water scarcity, its causes, and its solutions has been overlooked. No studies 
have been conducted on understanding the role of the discourse of water scarcity in promoting (or not) education for sustainable development in Jordan. This article makes this original contribution to knowledge.

The concept of discourse is central for this work. For Hajer, a discourse is "a specific ensemble of ideas, concepts and categories that are produced, reproduced and transformed in a particular set of practices and through which meaning is given to physical and social realities" (Hajer 1995: 44). For Hajer a discourse is constructed not through a single declaration, but rather through a number of actions, declarations, publications, and events, which support and constitute the construction and reproduction of a discourse. Actors construct and deploy discourses to push forward their interests towards their preferred solutions to the issue of water scarcity. Discourses are the place where and around which the power struggle between actors and different interests takes place. This article adopts Fairclough's conceptualisation of discourse. Similarly to Hajer's definition, for Fairclough a discourse is the whole process of social interaction, which includes the text and the processes of text production and interpretation, and their impact on the social practice (Fairclough, 2001: 20-21, Fairclough, 1992: 72-73). Hence, for Fairclough a discourse is the whole process that constructs, reproduces, and transforms the social reality through agents' actions, events, declarations, reports, etc. (ibid). A discourse is therefore constructed through a number of actions, declarations, publications, and events that support and constitute the construction and reproduction of a discourse, and it also considers the impacts of the deployment of the discourse on the solutions and the policies.

\section{METHODS AND DATA COLLECTED}

This section presents the methods deployed to collect the data needed to answer the research question. As seen above, the guiding research question of this study is:

- How does the Jordanian educational system construct the discourse of water scarcity?

Sub-research questions are:

- What causes of water scarcity are reproduced in the Jordanian textbooks?

- What solutions to water scarcity are suggested to students in the textbooks?

The data collection benefited from the deployment of a combination of different methods as well as intensive twelve months of fieldwork from December 2013 until 
December 2014 spread during different seasons in Jordan, and mainly in Amman, the capital of the country. This study makes use of qualitative methods of data collection. The methods of data collection deployed are:

- Document collection (main method);

- Semi-structured interviews.

The method of data analysis is discourse analysis, which allows investigation of the construction of the discourse. Data analysis has been undertaken through thematic coding for the textbooks, and after initial use of the NVIVO software for analysing the interviews, thematic coding has been applied for the analysis of the interviews. The themes and codes utilised for the analysis were the causes and reasons identified in the textbooks and by the interviewees for the issue of water scarcity, as well as the solutions they would suggest to solve the issue. ${ }^{2}$ Qualitative methods have been chosen as the focus of this study is on understanding the construction of the discourse of water scarcity through the lens of the Jordanian educational system. Given the research question guiding this study, the data to answer these questions are drawn from textbooks and from interviews to personnel from the Ministry of Education responsible for the national curricula and textbooks, to students, and to teachers. ${ }^{3}$

Concerning the sample of textbooks used for the analysis, the focus was on national curricula for primary and middle school from grade one until grade ten currently in use in Jordan. This article analyses the following textbooks: science for grade one till eight (Ministry of Education 2013d; 2013e; 2013f); geography from grade six until grade ten (Ministry of Education 2013b; 2013c); and earth and environmental science for grade nine and ten (Ministry of Education 2013a) (science is taught until grade eight, then it becomes earth and environmental science; geography is taught since grade six). The rational for the selection of this sample of textbooks has been selected after scoping interviews with teachers and governmental personnel from the Ministry of Education responsible for the national curricula, interviews aiming at identifying the subjects in which the issue of water scarcity is discussed. According to these interviews, the issue of water scarcity is discussed in the following subjects: science, geography, and earth and environmental science. The analysis of the textbooks aimed at identifying what was mentioned and what was not

\footnotetext{
2 This is further discussed in the next section on "Analysis."

${ }^{3}$ Below in this same section there are more information on the textbooks analysed and on the sample of interviewees.
} 
mentioned about water scarcity, how the issue was framed, what was more emphasised and what was overlooked. Also, the images and pictures used in the textbooks have been analysed, as they constitute part of the discourse and of the text constructing the discourse.

Given the research questions guiding this study, the analysis of the textbooks would be enough to answer the guiding questions. However, the deployment of the semi-structured interviews was useful to complement the understanding of how the educational system impacts students' understandings of the causes and potential solutions to the issue of water scarcity. Nevertheless, the main method of data collection was document collection, as textbooks, as discussed above, were the main source of data to answer the guiding questions of this research. During fieldwork, fifteen teachers working in schools in Amman, Irbid, Disi area, and in Wadi Araba have been interviewed. Those teachers were both junior and senior teachers responsible for delivering the modules of science for grade one till eight; geography from grade six until grade ten; and earth and environmental science for grade nine and ten, as those are the courses in which the issue of water scarcity is discussed. The teachers interviewed worked in ten different public schools, mainly in the big rural areas - both in rich neighbourhoods and in marginalised areas -, but also in rural and semi-desert areas. The choice of focusing on public schools was due to the fact that this article focuses on the national curricula and on the national textbooks produced by the Ministry of Education and utilised in public schools. The teachers were chosen often as they were the only ones responsible for delivering that course in the whole school (most schools, especially in the rural areas, are small schools and there are only a handful of teachers working in there). Otherwise, a snowball approach has been adopted to identify the teachers to interview. The sample of the schools was representative as they were both in urban, rural, and semi-desert regions of the country, in marginalised and rich areas. In addition, the outcome of the interviews was overall coherent with the responses of all teachers interviewed. The teachers have been interviewed multiple times during the fieldwork, exploring mainly what were the discussions in the classrooms when the issues of water and water scarcity were discussed. In addition, forty-six students - both females and males - that have recently completed their schooling education - and therefore over 18 years old - have been interviewed. In most cases, the students have attended the same schools where the teachers interviewed are working. The students have been selected in the same 
communities where the schools are based, and mainly through a snowball approach. The students have been asked the following questions:

- Is there water scarcity in Jordan?

- What are the causes for water scarcity?

- What are the solutions for water scarcity?

- How do you know what you have been telling me?

In addition - in line with a semi-structured method of data collection - they have also been asked some follow up questions, according to how they answered the questions listed above. As mentioned above, the semi-structured interviews aimed in sketching trends of how the issue of water scarcity is understood among students; however, this is only a snapshot, a picture, of a small sample of students, and it does not seek to be a quantitative representative sample of the whole students population in the country. Nevertheless, this snapshot is useful as it provides patterns that are homogenous and to complement the analysis of the textbooks, as further discussed in the analysis section.

\section{ANALYSIS}

This section analyses the content of the textbooks to investigate what discourse of water scarcity is constructed in the textbooks. This section argues that the analysis of the textbooks and of the interviews with students and teachers - as discussed below in this section - shows that the educational system contributes to: construct and reproduce the discourse of water scarcity in Jordan; shape students' understanding of the water issue; make water scarcity an urgent issue; construct the understanding that water scarcity is mainly due to environmental or political reasons and not to the mismanagement of the water resources in the country; and drive mainly towards a trend of supply side solutions - meaning increasing the water resources - rather than towards a better management of water resources in the country (Hussein 2016).

\section{Table 1: Interviews to students}

\begin{tabular}{|c|c|}
\hline Questions & Responses \\
\hline Is there water scarcity in Jordan? & $\begin{array}{ll}- & \text { Yes (46 students) } \\
\text { - } & \text { No (0 students) }\end{array}$ \\
\hline $\begin{array}{l}\text { What are the causes for water } \\
\text { scarcity? }\end{array}$ & $\begin{array}{ll}\text { - } & \begin{array}{l}\text { Population growth and refugees } \\
\text { students) }\end{array} \\
\text { - } & \text { Neighbouring countries (42 students) }\end{array}$ \\
\hline
\end{tabular}




\begin{tabular}{|c|c|}
\hline & $\begin{array}{ll}\text { - } & \text { Climate change (35 students) } \\
\text { - } & \text { Low precipitations and natural aridity (37 } \\
& \text { students) }\end{array}$ \\
\hline $\begin{array}{l}\text { What are the solutions for water } \\
\text { scarcity? }\end{array}$ & 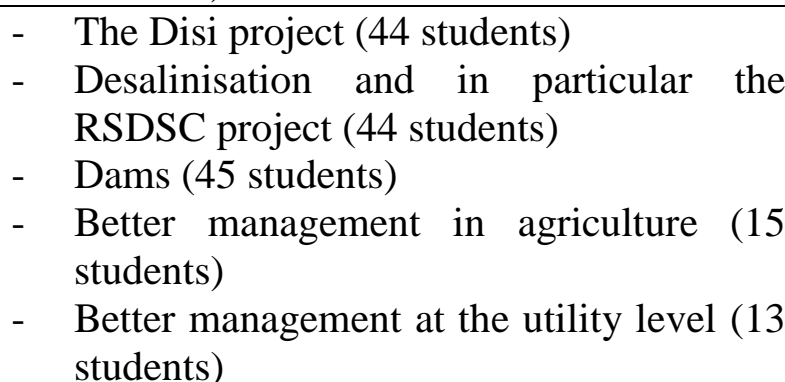 \\
\hline $\begin{array}{l}\text { How do you know what you have } \\
\text { been telling me? }\end{array}$ & 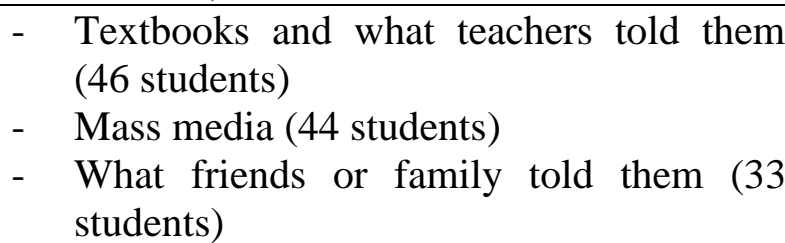 \\
\hline
\end{tabular}

Source: Author's own compilation

As showed in Table 1, the pattern of answers received from students is that primary education and textbooks played a central role in constructing students' perceptions and understandings of the issue of water scarcity. They all agreed that water scarcity is a serious issue in the country, one of the most serious environmental challenges for Jordan. The second point that emerges is that their awareness of this issue is due to the textbooks and to the educational system. In fact, they explained that they are aware of these issues because they learned them at school from the textbooks and from their teachers, as well as from mass media. The results of the interviews summarised in Table 1 confirm the survey study findings on environmental awareness conducted in Jordan by Zyadin et al., which found that "school students placed fresh water shortage as the prime environmental challenge in Jordan an everyday-life problem to every citizen" (Zyadin, Papasozomenou et al. 2015: 152). Textbooks analysis showed that the overall discourse of water scarcity is reproduced through all the references on water in the textbooks across all disciplines. For instance, in the textbook of science for grade three, it is said that "most countries suffer from water scarcity. Jordan is one of them" (Ministry of Education 2013e: 57). Table 1 shows that the interviews underlined that for the students the causes of water scarcity in Jordan are due to the following reasons: population growth, neighbouring countries, climate change, and low precipitations. These reasons are the same one that are emphasised in the textbooks and that are usually discussed in the classroom, 
according to a geography teacher responsible for preparing the national curricula (Interview 2).

Concerning the policy implied in the textbooks and in the educational system, this paragraph argues that throughout the textbooks, it emerges an emphasis on the supply side solutions, backed by the norm that engineering interventions are the solution to the water scarcity problem and the discourse of the hydraulic mission of the state. Hydraulic mission, a key discourse in hydropolitics, refers to the selfproclaimed mission of the state to expand irrigation through mega-projects of hydraulic infrastructural nature, mainly dams (Allan 2001: 28-30; 180). This paragraph argues that the construction of dams, water harvesting, and the Disi and Red Sea - Dead Sea Canal (RSDSC) projects are strongly supported in the textbooks and never questioned. This emerges in the textbooks in several instances, for instance when in order to conserve more water, students are invited several times to discuss what the best ways to collect rain water are, and the solutions suggested are dams and private wells (Ministry of Education 2013e: 23). In this volume, there were three pictures of dams, as good examples to save and conserve water. In the textbook of science for grade three, as an example of surface water is given a dammed river, showing the dam as something normal and natural (Ministry of Education 2013e: 19). In the same textbook, a page is titled "What are the sources of water in Jordan?" and four pictures are provided, two of them showing Jordanian dams, the third one showing the King Abdullah Canal, and the fourth one showing water falls (Ministry of Education 2013e: 23). This means that three out of four pictures on water resources in Jordan reproduce the hydraulic mission of the state and three mega-projects. On page 24 (ibid.), students are asked: "how can we conserve and capture rainwater? Why we need to build dams? What happens to water if there are no dams?" In order to answer these questions, students are asked to look at the big figure in the centre of the page: a big picture of a dam. This shows how dams are the sanctioned solution. On page 28 (ibid.), this message is even clearer: in a box titled "read and learn: In Jordan there are few sources of surface and groundwater. We need to conserve rainwater through dams. It is our duty to preserve water." On page 60 (ibid.), there is a drawing of a dam and questions below asking the students "what is that? What is the goal of building dams?" So far, it results that all students of Jordan between grade one and three have been exposed to and may begin to internalise that there is water scarcity in Jordan and the natural solution are the dams. In the textbook of geography 
for grade eight, on page twenty there is a map showing the major rivers in the Arab World, and only one picture of King Talal Dam in Jordan and the title of the page is surface water in the Arab world (Ministry of Education 2013b: 20). One teacher of geography said about the Disi project that in the edition that they are working on, they will talk about the project of Disi-Amman, and on how this project is positively helping Amman and Zarqa for domestic water supply (Interview 2). The RSDSC project is also presented. As underlined by a geography teacher from the ministry of education, since grade nine the issue of the RSDSC project is discussed, showing the positive aspects of the project in order to counter the negative popular discourses with no scientific basis of: the RSDSC project as a collaboration with Israel and of the environmental impacts of the project (Hussein, 2017). The environmental impacts are mentioned, but with a focus on the positive aspects, such as saving the Dead Sea (Interview 2). In line with the solutions promoted in the textbooks, also the interviews - as summarised in Table 1 - showed that the solutions to water scarcity identified by students were on the supply side: the Disi project, desalinisation- in particular the RSDSC project -, and dams.

However, also issues like the unsustainable water use in agriculture and nonrevenue water $(\mathrm{NRW})^{4}$ are mentioned in the textbooks, presenting the necessity of working also on the demand side, but with different emphasis. In the geography textbook for grade ten, the inefficiency in agriculture is discussed, providing the data of its impact on GDP, 2,1\% in 2003, and the contribution of the labour force, $6,1 \%$ (Ministry of Education 2013c: 47). The foreign labour working in the sector is also mentioned, and it is suggested to be high compared to the other sectors. In grade five in the science textbook they learn about the amount of supply versus demand in the water sector, and analyse the percentages of water used in the different sectors (Ministry of Education 2013f: 170). Suggested solutions are more efficiency in agriculture through drip irrigation techniques, wastewater treatment, maintenance of the water network, and wells for water harvesting (Ministry of Education 2013f: 171).

Conservation solutions are also suggested, mainly through behavioural change campaigns and practices. Students are suggested to decrease the waste of water,

\footnotetext{
${ }^{4}$ Unaccounted for Water (UFW) is water produced by a provider but not billed due to losses, illegal uses, and wrong metering. Instead, NRW includes UFW plus authorised unbilled uses like uses for public buildings, fire-fighting, etc. (IB-NET, 2005). In the case of Jordan most reports use NRW rather than UFW. For this reason, it is more practical to consider NRW rather than UFW for the scope of this research.
} 
change their behaviour, as this would be in line with what the Prophet once said when he "saw Sa'd performing ablution and said to him: "Why are you wasting all this water?' Sa'd asked, 'Is there wastefulness even in performing ablution?' The Prophet replied, 'Yes, even if you were at a flowing river'" (Ministry of Education 2013f: 173). In the textbook of science for grade one, the focus is raising awareness to reduce consumption at the household level, teaching pupils on how to reduce water consumption as "water is a good from God, so we need to conserve it" (Ministry of Education 2013d: 21). In the earth and environmental sciences ninth grade textbook, a section is dedicated to water management in Jordan (Ministry of Education 2013a: 31-32). The solutions identified to solve water scarcity in Jordan are:

“1) Developing water resources

2) Expanding water projects

3) Water conservation

4) Introducing Islamic approaches for water management

5) Wastewater treatment

6) Monitoring of groundwater to reduce their exploitation

7) Continuing to search for new sources of water, including: water harvesting, desalination, rainwater harvesting, building dams, and digging new wells

8) Raising awareness to improve efficient use in the three sectors: agriculture, domestic, industrial” (ibid.).

This list includes a majority of supply side solutions, with the hydraulic mission of the state emerging in many of the suggested solutions. These supply side solutions occupy high positions in this list too. Demand side solutions are either in the form of conservation, or grouped together in the last of the eight suggested solutions.

The geography teacher added that in grade twelve they speak about political transboundary water governance (TWG) relations: they mention the quotas and allocations. They also say that Syria is not always respecting the agreement, as well as Israel in the past. They only give the facts and data on these issues, without judgements, and they are provided with these "objective data" from the Institute of Geography, the MWI, and the Department of Statistics (Interview 2). However, as argued in the methodological and theoretical approach section, while there is an 
objective reality out there, descriptions and representations of it are mediated by our own lenses.

\section{DISCUSSION/CONCLUSION}

This article made three original contributions to knowledge. The first one is using textbooks to explore representation of water scarcity in Jordan. The second one is the content of the analysis of the representation of the issue of water scarcity in the textbooks and through the interviews. The third one situates the discourse of water scarcity within education for environmental sustainability.

The first contribution is about the decision to investigate the discourse of water scarcity through primary education and through the role of textbooks in particular. The choice of textbooks (documentation) and semi-structured interviews as methods of data collection is linked to the data required to understand how textbooks frame the issue of water scarcity. The choice of these methods is made because documentation represents what Fairclough sees as text based sources of interpretation of a discourse and the semi-structured interviews allow investigation of the interests behind the documentation, and the stories behind choosing, for instance, to reproduce certain discourses rather than others or framing the issue of water scarcity in one way rather than in a different one. Given the central role of the educational system and of textbooks in particular in producing and reproducing the discourses of water scarcity in Jordan, the data collection methods have been applied to the educational sector. Semi-structured interviews were key for the critical approach adopted. The interviews made it possible to go beyond the textbooks, and understand how the issue is portrayed in this way, how it is taught by teachers, and perceived by students. The interviews with the teachers also helped in understanding what were the questions usually asked on this topic by students - mainly mainstream, acritical questions, confirming the discourses reproduced by the textbooks -, and how the debates in the classroom about the issue of water scarcity evolved and developed. Finally, interviews with students who just finished school were useful to capture their perceptions over the issue of water scarcity, perceptions in most cases constructed through what they have learned at school and read on the textbooks. This article showed the relevance of using documentation - textbooks - and semi-structured interviews to students and teachers to collect data to understand representation and perception of water scarcity in the educational system Jordan. The methods allowed to 
look at the issue from different perspectives: textbooks, teachers, students, and relevant governmental institutions. The interviews complemented the documentation by providing insights on the interests, reasoning behind, and power struggles.

The second original contribution of this article is about the content related to the issue of water scarcity reproduced by textbooks and by the educational system. Overall, this article showed that the water scarcity discourse is represented mentioning all reasons for water scarcity identified by Hussein (2016). However, in the textbooks only the solutions that are not conflicting with the powerful stakeholders do appear and are strongly supported, meaning supply side solutions and conservation solution. Focusing on what is missing from the textbooks, it appears that in order to make the agricultural water use more sustainable, only drip irrigation and more technological techniques are suggested. Regulations on the type of crops, tariffing systems and subsidies removal are never mentioned. It also appears that certain solutions are particularly supported, emphasised, and promoted: the hydraulic mission, the construction of dams, water harvesting, and wells. Also, the mega projects are strongly supported, in particular the Disi and the RSDSC projects, emphasising their positive aspects. However, also solutions for water conservation are promoted, with a strong emphasis on raising awareness, on what the students can do in their daily life, aiming at changing their behaviours in their water related lifestyle often through the use of religious anecdotes. The framings for the causes of water scarcity promoted by and in the textbooks drive mainly towards a trend of supply side solutions - meaning increasing the water resources - or conservation, rather than towards a better management of water resources through demand side solutions meaning reducing the current demand for water resources. Therefore, in a nutshell it emerges that the textbooks contribute to reproduce the same water scarcity discourse, emphasising the supply side solutions but also mentioning the demand side and conservation ones, unless they are conflicting with the interests of the powerful stakeholders.

The third contribution of this article is investigating to what extent the discourse of water scarcity constructed in the educational system in Jordan contributed to education for environmental sustainability. As analysed in the previous section, the discourse of water scarcity as constructed and reproduced in the textbooks, provides best practices and aims at shaping behaviour of students towards the environment. This is particularly the case in water conservation, suggesting students to use water 
more efficiently and reduce the waste of water at the domestic level as well as in gardening and farming practices. Religious practices and norms are also mobilised to support water efficiency and to shape students' behaviour towards environmental sustainability. In this sense, Jordanian textbooks drive towards what Tilburn (1995) calls environmental sustainability, focusing on the long-term, and on empowering citizens to become actors of change, changing their daily behaviour towards the use of environmental resources. This is resulting in changes in students' behaviour at the domestic level, as demonstrated by Zyadin (2015) et al. and Middlestadt et al. (2001). The latter showed through a study in Jordan that students using new curricula with the integration of a special water programme are more likely to implement water wise practices at the household level (Middlestadt, Grieser et al. 2010). Nevertheless, some of the solutions on the supply side suggested to solve the issue of water scarcity are believed to be unsustainable for the environment in the long term, for instance the Disi canal project and the Red Sea-Dead Sea canal project. In these two cases, it emerges that the focus is more on economic and social aspects rather than on the environmental one. However, these two policy-options are targeting the government and policy makers rather than students. Overall, this article showed a strong push towards increasing awareness of environmental issues, in this case water scarcity in Jordan, not only describing it as a natural and an apolitical phenomena, but making students part of it. Students are empowered and taught that they can contribute to be part of the solution through changing their daily behaviour, and also by showing them inconsistencies in the current water allocations per sectors, being in this way driving towards teaching practices of environmental sustainability.

\section{REFERENCES}


Allan, T. (2001). The Middle East water question: Hydropolitics and the global economy, lb Tauris.

Caravita, S., et al. (2008). "Construction and Validation of Textbook Analysis Grids for Ecology and Environmental Education." Science Education International 19(2): 97-116.

El-Naqa, A. and A. Al-Shayeb (2009). "Groundwater protection and management strategy in Jordan." Water resources management 23(12): 2379-2394.

Fairclough, N. 1992. Discourse and social change. Cambridge: Polity, 7.

Fairclough, N. 2001. Language and power, Pearson Education.

FAO (2009). "Irrigation in the Middle East region in figures: AQUASTAT Survey - 2008 ".

Garber, A. and E. Salameh (1992). "Jordan's water resources and their future potential." Water Research and Study Centre, University of Jordan.

Ghazal, M. (2016). "Population stands at around 9.5 million, including 2.9 million guests " The Jordan Times 30 January 2016.

Gough, A. (2013). "Historical, contextual, and theoretical orientations that have shaped environmental education research."

Gough, N. and L. Price (2004). "Rewording the world: poststructuralism, deconstruction and the 'real'in environmental education." Southern African Journal of Environmental Education 21: 23-36.

Haddadin, M. J. (2006). Water resources in Jordan: evolving policies for development, the environment, and conflict resolution, Resources for the Future.

Hajer, M. A. (1995). The politics of environmental discourse: ecological modernization and the policy process, Oxford University Press Oxford.

Hussein, H. (2016). "An analysis of the discourse of water scarcity and hydropolitical dynamics in the case of Jordan." PhD Thesis University of East Anglia

Hussein, H. 2017. Politics of the Dead Sea Canal: a historical review of the evolving discourses, interests, and plans. Water International, 42(5), 527-542.

Hussein, H., and Grandi, M. (2015). "Contexts matter: A hydropolitical analysis of Blue Nile and Yarmouk River Basins." Social Water Studies in the Arab Region 159.

Hussein, H., and Grandi, M. (2017). "Dynamic political contexts and power asymmetries: the cases of the Blue Nile and the Yarmouk Rivers." International Environmental Agreements: Politics, Law and Economics.

ISSP (2012). "Water valuation study: disaggregated economic value of water in industry and irrigated agriculture in Jordan ". 
Jacobs, M. (1993). The green economy: Environment, sustainable development and the politics of the future, UBC press.

Jassim, H. and M. AlRaggad (2009). "GIS Modeling of the Effects of Climatic Changes on the Groundwater Recharge in the Central Western Parts of Jordan." Jordan Journal of Civil Engineering 3(4).

Kincheloe, J. L. (2005). Critical constructivism primer, Peter Lang.

Mahasneh, R. A., et al. (2017). "Reading social stories in the community: A promising intervention for promoting children's environmental knowledge and behaviour in Jordan", The Journal of Environmental Education

Marcinkowski, T., et al. (2013). "Selected Trends in Thirty Years of Doctoral Research in Environmental Education in Dissertation." International handbook of research on environmental education: 45.

Massad, J. A. (2001). Colonial effects: The making of national identity in Jordan, Columbia University Press.

Mehlinger, H. D. (1985). "International textbook revision: Examples from the United States." Internationale Schulbuchforschung: 287-298.

Middlestadt, S., et al. (2010). "Turning minds on and faucets off: Water conservation education in Jordanian schools." The Journal of Environmental Education 32(2): 37-45.

Ministry of Education (2013a). "Textbook of Earth and Environmental Sciences. 9th grade, second part (in Arabic)."

Ministry of Education (2013b). "Textbook of Geography, 8th grade, first part (in Arabic)."

Ministry of Education (2013c). "Textbook of Geography, 10th grade, first part (in Arabic)."

Ministry of Education (2013d). "Textbook of Science. 1st grade, second part (in Arabic)."

Ministry of Education (2013e). "Textbook of Science. 3rd grade, second part (in Arabic)."

Ministry of Education (2013f). "Textbook of Science. 5th grade, second part (in Arabic)."

Murphy, E. (1997). "Constructivism: From Philosophy to Practice."

MWI (2013). "Cost of hosting Syrian refugees on water sector of Jordan."

MWI (2014). "Water Budget 2012-2013."

Namrouqa, H. (2012). "Jordan's critical water situation highlighted " The Jordan Times 19 March 2012.

Namrouqa, H. (2014). "Jordan world's second water-poorest country." The Jordan Times 22 October 2014. 
Newport, D., et al. (2003). "The "environmental sustainability" problem: ensuring that sustainability stands on three legs." International Journal of Sustainability in Higher Education 4(4): 357-363.

Podeh, E. (2000). "History and memory in the Israeli educational system: The portrayal of the Arab-Israeli conflict in history textbooks (1948-2000)." History \& Memory 12(1): 65-100.

Podeh, E. (2005). Arab-Israeli Conflict in Israeli History Textbooks, 1948-2000, IAP.

Rawashdeh, R. e. (2012). "Jordanians and Syrian refugees share the water shortage problem." Al Rai 02/09/2012.

Sitarz, D. (1993). "Agenda 21: The earth summit strategy to save our planet."

Stevenson, B., et al. (2013). "International handbook of environmental education research." New York \& London: Routledge.

Tilbury, D. (1994). Environmental education: developing a model for initial teacher education, University of Cambridge.

Tilbury, D. (1995). "Environmental education for sustainability: Defining the new focus of environmental education in the 1990s." Environmental education research 1(2): 195-212.

Von Glasersfeld, E. (1995). "A constructivist approach to teaching." Constructivism in education 3: 15.

Williams, J. H. (2014). (Re) Constructing memory: School textbooks and the imagination of the nation, Springer.

Wright, T. S. (2002). "Definitions and frameworks for environmental sustainability in higher education." International Journal of Sustainability in Higher Education 3(3): 203-220.

Zyadin, A., et al. (2015). "Environmental Awareness and Perceptions among Young School Students in Jordan." Social Water Studies in the Arab Region: 141. 